\title{
Rевевсн автіске: Isolation and characterization of organ phosphorus pesticide degrading bacteria from different crops
}

\author{
R. GIREESH KUMAR, A. VIJAYA GOPAL, R. SUBHASH REDDY AND S. \\ TRIVENI
}

Article Chronicle : Received :

19.07.2017;

Accepted :

03.08.2017

KEY Words :

Phorate degrading

bacteria, Enrichment,

Degradation

efficiency,

Pseudomonas spp.,

Bacillus spp.

Author for correspondence :

\section{R. GIREESH KUMAR}

Department of

Agricultural

Microbiology and

Bioenergy, College of

Agriculture, Prof Jaya

Shankar Telangana State

Agricultural University,

Rajendranagar,

HYDERABAD

(TELANGANA) INDIA

Email :

gireeshkumarravuri@ gmail.com

See end of the article for authors' affiliations
SUMMARY : In the present work total eight bacterial isolates were obtained from insecticide treated maize and ground nut rhizospheric soils by enriching Mineral Salt Medium broth with supplement of Phorate source. These isolates were characterized on the basis of cell morphology, cultural and biochemical properties. Isolates were screened for their phorate degradation capability in liquid cultures. Among the eight phorate degrading bacterial isolates, PDB-1 showed the high population count at different incubation periods ( $\left(1^{\text {st }}\right.$ day to $5^{\text {th }}$ day) compared to all Phorate degrading bacterial(PDB) isolates. The Phorate degrading bacteria (PDB)-1 isolate utilized the pesticide (Phorate) effectively and showed maximum bacterial count $5.9 \mathrm{cfu} \times 10^{6} \mathrm{ml}^{-1}$. Phorate degrading efficiency of isolates was determined by measuring the phorate residual concentrations at intervals using Gas chromatographic method. The degradation of Phorate at different concentrations (20,30 and $\left.40 \mathrm{mg} \mathrm{l}^{-1}\right)$ was examined in the Mineral salt liquidmedium. By this degradation percentage study of Phorate revealed that the Phorate degrading bacterial isolate (PDB-1) degrade the Phorate effectively.

How to cite this article : Kumar, R. Gireesh, Gopal, A. Vijaya, Reddy, R. Subhash and Triveni, S. (2017). Isolation and characterization of organ phosphorus pesticide degrading bacteria from different crops. Agric. Update, 12(TECHSEAR-7) : 1927-1932; DOI: 10.15740/HAS/AU/12.TECHSEAR(7)2017/1927-1932. 